FOLIA POMERANAE UNIVERSITATIS TECHNOLOGIAE STETINENSIS

Folia Pomer. Univ. Technol. Stetin., Oeconomica 2017, 339(89)4, 15-28

Agnieszka BRELIK, Ireneusz ŻUCHOWSKI ${ }^{1}$

\title{
COMPETENCIES OF CONTEMPORARY MANAGERS
}

\section{KOMPETENCJE WSPÓŁCZESNYCH MENEDŻERÓW}

Dean's Representative for International Educational Cooperation, West Pomeranian University of Technology, Szczecin, Żołnierska 47,71-210 Szczecin, Poland, e-mail: agnieszka.brelik@zut.edu.pl 1 Department of Management and Economics, Higher School of Agribusiness

Studencka 19, 18-400 Łomża, Poland, e-mail: ireneusz.zuchowski@wsa.edu.pl

\begin{abstract}
Streszczenie. W części teoretycznej artykułu omówiono znaczenie kompetencji, wskazując, które z nich są najważniejsze w odniesieniu do badań różnych autorów. Omówiono wybrane modele kompetencji menedżera. Zaprezentowano również wyniki badań własnych. Badania przeprowadzono wśród 200 menedżerów z małych i średnich przedsiębiorstw z województw mazowieckiego i podlaskiego, reprezentujących trzy szczeble zarządzania. Celem badań było poznanie opinii menedżerów na temat znaczenia niezbędnych kompetencji i umiejętności. Badania własne oraz literatura wskazują, że jedną z kluczowych umiejętności współczesnego menedżera staje się umiejętność budowania relacji ze współpracownikami.
\end{abstract}

Słowa kluczowe: współczesny menedżer, cechy menedżera, umiejętności menedżera.

Key words: contemporary manager, managerial qualities, managerial skills.

\section{INTRODUCTION}

A manager is an essential part of business management. He or she determines their functioning and efficiency. To properly carry out their tasks, he or she should display certain qualities and skills. Nowadays, it is still a serious problem as the profession of manager has not been defined properly. Attempts are made to identify and define the skills and characteristics that a manager should have. This is related to the processes of changes that occur in the environment of enterprises, in particular, the changes in the labour market as well as the entry of new generations of workers into this market. Contemporary managers should show many different skills, however, depending on the ruling level their range may vary. Molinsky's research together with other studies, point out the three skills that a 21st century manager should acquire. Among these are: the ability to work in an intercultural environment, the ability to use digital technology and the divisibility of attention (Molinsky et al. 2012). The American Association of Management mentions management skills, critical thinking, finance, communication, collaboration and project management as essential managerial skills (6 Skills that will... 2017). A review of research on the skills and roles of managers is presented by Papulová and Mokroš (2007). The authors cite, among others, the study conducted in Slovakia by Papula (1995) which allowed identifying the following skills that a manager should display: 
- creativity - the ability to search and find new solutions,

- intuition - the ability to predict the future development based on their own experiences,

- focus on objectives - the ability to formulate realistic objectives and determining their hierarchy,

- responsibility - integrity in achieving its objectives and tasks,

- confidence - faith in its own strength and capacity to achieve the goals,

- initiative - an attempt to search for new possibilities and solutions for achieve your goals,

- independence - the courage to make decisions based on their own assessment,

- care - decision making ability under conditions of stress and uncertainty,

- conscientiousness - the promotion of values and social norms,

- discipline - self-control and adjustment of their own behaviour,

- perseverance - the ability to overcome barriers to the attainment of the objectives,

- optimism - focus on objectives and positive attitude, belief in success,

- fantasy - creating a vision the future.

Managers of the future should be able to react to the changing environment (Burgoyne et al. 2004). A comprehensive analysis of the necessary skills that the manager should have is also presented by prof. Kaczmarek in his work, "Contemporary Challenges for Business Management". The author points out that in the future the Polish manager should have the following characteristics:

- ability to conduct negotiations,

- ability to mobilize,

- risk taking,

- call of duty,

- ability of anticipation,

- ability to decide,

- ability to listen to others,

- ability to motivate,

- persistent pursuit of the goal,

- confidence in behaviour (Kaczmarek 2016).

The above indicate that it is necessary to update knowledge about the necessary traits and skills of the managers. The aim of the article is to identify the skills and characteristics of modern managers based on their opinions.

\section{MODELS OF MANAGERIAL COMPETENCY ASSESSMENTS}

Competency can be distinguished at individual, organizational and strategic level. At the individual level, competency is defined as the potential of knowledge and skills, abilities and competences of employees (Khorasani et al. 2014).

The managerial competencies assessment standards all require competence from the manager. These include both their inventory and the description (Levy-Leboyer 1997). The competency assessment model and competency model are used interchangeably. A competency model is a reference system to which the specific competencies of managers are compared. 
Table 1. Models of key managerial competencies

\begin{tabular}{|c|c|}
\hline Author & Competencies \\
\hline $\begin{array}{l}\text { A. Rakowska, } \\
\text { A. Sitko Lutek }\end{array}$ & $\begin{array}{l}\text { 1. „Technical skills (knowledge) - they relate to technical and specialized knowledge } \\
\text { related to the work performed in the areas of management, law, finance, human } \\
\text { resources, marketing. } \\
\text { 2. Developing your own ability - the analysis of your own strengths and weaknesses, } \\
\text { planning your own development. } \\
\text { 3. Managing stress - effective use of time management methods, setting hierarchy of } \\
\text { activities, increasing physical and mental stress resistance, delegating tasks. } \\
\text { 4. Conceptual skills - problem solving, ability to analyse and synthesize information, } \\
\text { creative thinking, creating an atmosphere for innovation. } \\
\text { 5. Communication skills - creating a supportive atmosphere for conversation, giving } \\
\text { advice to employees, criticizing, creating information channels in an organization. } \\
\text { 6. Motivation skills - skilful use of various motivations (economic and non-economic), } \\
\text { rewarding outstanding accomplishments, motivating assignments, executing tasks. } \\
\text { 7. Gaining power and influence: identifying and shaping the sources of power, skilfully } \\
\text { exerting influence. } \\
\text { 8. The ability to resolve conflicts: identification of the sources of conflicts, accepting } \\
\text { criticism, dispute mediation, seeking constructive conflict solutions. } \\
\text { 9. Team work skills: using group decision-making techniques, organizing meetings, public } \\
\text { presentation, adjusting the group's leadership style to the situation. } \\
\text { 10. Implementing changes - listening to comments and discussing necessary changes } \\
\text { with subordinates, developing plans with superiors. " }\end{array}$ \\
\hline $\begin{array}{l}\text { Ch.B. Adair, } \\
\text { B.A. Murray }\end{array}$ & $\begin{array}{l}\text { "The Competencies of Managers Implementing Innovations Successfully: } \\
\text { 1) competencies related to the value system: recognition for the individual, self-esteem, } \\
\text { recognition for achievement and vigorous activity, seeking better solutions, } \\
\text { 2) competencies related to character traits: the transfer of a clearly defined, value-for- } \\
\text { money vision, the discovery of other people's abilities, the release of positive energy, } \\
\text { the achievement of team success, demonstration of initiative and adaptability. " }\end{array}$ \\
\hline A. Pocztowski & $\begin{array}{l}\text { 1) "threshold competencies - essential for the proper performance of a given job, i.e. } \\
\text { knowledge and skills, and in the case of a manager they include expertise, problem } \\
\text { solving, communication, relationship formation and the use of counselling services, } \\
\text { 2) differentiating competencies - the competencies that distinguish an effective worker } \\
\text { from others, including attitudes, motives and values, and in the case of managerial } \\
\text { leadership, empathy, readiness to learn, tolerance for ambiguity, attitude towards } \\
\text { creativity, orientation for the future, consciousness values." }\end{array}$ \\
\hline H. Guryn & $\begin{array}{l}\text { 1. ",ore competencies - are essential for all managerial positions in an organization; the } \\
\text { level of core competencies is determined equally for all, regardless of the organizational } \\
\text { role played; } \\
\text { 2. key competencies - the strongest influence on the proper performance of tasks related } \\
\text { to a given position; assimilation of these competencies is a prerequisite for effective } \\
\text { work; for each position, several key competencies are defined in different combinations } \\
\text { and at different levels depending on the functions performed; } \\
\text { 3. specific competencies - specific to a particular managerial position in a company, they } \\
\text { address specific requirements in terms of specialist knowledge, skills or attitudes." }\end{array}$ \\
\hline G. Filipowicz & $\begin{array}{l}\text { 1. „Basic Competencies: } \\
\text { cognitive competencies: problem solving, willingness to learn, broad horizons, flexibility } \\
\text { of thinking, creativity, } \\
\text { - social competencies: negotiation, international relations, relationships with superiors, } \\
\text { relationships with colleagues, written communication, comprehensibility, presentation } \\
\text { skills, influence, teamwork, propriety, } \\
\text { - personal competencies: orientation to action, initiative, coping with stress, } \\
\text { persistence, commitment, effectiveness, self-organization, conscientiousness, } \\
\text { decision making, prioritizing, pursuing results, confidence. } \\
\text { 2. Executive competencies: } \\
\text { - business competencies: business orientation, industry knowledge, customer needs } \\
\text { analysis, sales techniques, } \\
\text { - corporate competencies: corporate identity, customer focus, openness to change, } \\
\text { ethics and values, foreign languages, organizational efficiency, expertise, } \\
\text { - management competencies: team building, subordinate care, delegation, motivation, } \\
\text { managerial courage, leadership, organization, planning, process management, } \\
\text { project management, strategic thinking, change management. }\end{array}$ \\
\hline R. Walkowiak & $\begin{array}{l}\text { "Competencies of managers in self-government organisations: } \\
\text { 1) professional competencies (knowledge and skills ensuring efficient and effective } \\
\text { managing of an organisation), }\end{array}$ \\
\hline
\end{tabular}


Table 1. Models of key managerial competencies (cont.)

\begin{tabular}{|c|c|}
\hline Author & Competencies \\
\hline & $\begin{array}{l}\text { 2) social competencies (knowledge of attitudes and behaviours of individuals and teams, } \\
\text { and the ability to cause action in accordance with the objectives of the organisation and } \\
\text { its members), } \\
\text { 3) business competencies (entrepreneurial capacities leading to profitable operations)." }\end{array}$ \\
\hline T. Oleksyn & $\begin{array}{l}\text { "Expected managerial competencies of various levels of management are partly common, } \\
\text { and partly different. In connection to this it is appropriate to take into consideration the } \\
\text { requirement specifications of different levels of management and distinguish the following } \\
\text { managerial competencies: } \\
\text { 1) senior management: future orientation, personality and social competence, } \\
\text { 2) middle management level: interpersonal and innovative competencies, } \\
\text { 3) lower level of management: technical competencies (substantive in particular field)." }\end{array}$ \\
\hline A. Rakowska & $\begin{array}{l}\text { "Classification includes } 11 \text { groups of managerial skills: expertise, foreign languages, self- } \\
\text { management, managing stress, conceptual skills, communication, motivation, organisation } \\
\text { and control, exerting influence, problem solving, team work, implementing changes." }\end{array}$ \\
\hline $\begin{array}{l}\text { R.E. Quinn, } \\
\text { S.R. Faerman } \\
\text { M.P. Thompson, } \\
\text { M.R. McGrath }\end{array}$ & $\begin{array}{l}\text { „8 functions of managerial leadership and related core competencies: } \\
\text { 1. Function of the mentor: understanding oneself and others, effective communication, } \\
\text { employee development. } \\
\text { 2. Function of the moderator: building teams, group decision-making, managing conflicts. } \\
\text { 3. Monitoring function: managing information through critical thinking, coping with } \\
\text { information overload, managing basic processes. } \\
\text { 4. Function of Coordinator: project management, designing work, interfunctional mana- } \\
\text { gement. } \\
\text { 5. Marshalling function: formulating and passing vision, goal-setting, planning and } \\
\text { organising. } \\
\text { 6. Executor function: personal effectiveness, caring for the environment productivity, time } \\
\text { management and coping with stress. } \\
\text { 7. Intermediary function: building and maintaining the fundamentals of power, negotiating } \\
\text { agreements and liabilities, presenting a concept: effective verbal presentations. } \\
\text { 8. Innovation function: accepting changes, creative thinking, managing change." }\end{array}$ \\
\hline J. Wieczorek & $\begin{array}{l}\text { "Management competencies: team building, building engagement, delegating tasks, non- } \\
\text { financial motivating, monitoring performance, courage in making the decision, translating } \\
\text { strategic objectives to operational tasks, leadership, assisting the development of } \\
\text { subordinates, recruitment of staff, determination of purpose, exerting influence. " }\end{array}$ \\
\hline $\begin{array}{l}\text { A. Heyde, } \\
\text { B. Linde }\end{array}$ & $\begin{array}{l}\text { "Important executive competencies: the ability to analyse, focus on performance and } \\
\text { achievement of results, the ability to motivate, focus on purpose, the ability to put } \\
\text { intentions into action and take part in conflicts, the ability of empathy and flexibility in the } \\
\text { relations, the power of persuasion and the ability to communicate, strategic thinking, for } \\
\text { the needs of the company, self-reflection and the willingness to change. " }\end{array}$ \\
\hline J. Czekaj & $\begin{array}{l}\text { "The framework of the leadership competencies: } \\
\text { 1) basic competencies } \\
\text { - general - arising from formal education, } \\
\text { - occupational - depending on training and seniority, } \\
\text { - intellectual - depending on general knowledge level, } \\
\text { 2) professional Competencies } \\
\text { - managerial - resulting from the certificate } \\
\text { - completed training, } \\
\text { - IT - resulting from knowledge of information systems, } \\
\text { - negotiating - resulting from participation in negotiations, } \\
\text { - mediatory - resulting from cooperation and conflict resolution." }\end{array}$ \\
\hline
\end{tabular}

Source: Tyrańska (2011), p. 113-116. 
Table 2. Competency model for managers (CMDM)

\begin{tabular}{|c|c|c|c|c|c|c|c|}
\hline \multicolumn{2}{|c|}{ Level / categories } & \multicolumn{2}{|c|}{ Strategic level } & \multicolumn{2}{|l|}{ Tactical level } & \multicolumn{2}{|c|}{ Operational level } \\
\hline \multirow{3}{*}{ 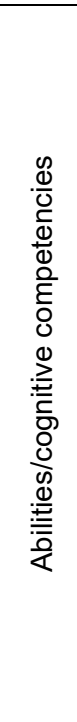 } & knowledge & $\begin{array}{l}\text { knowledge of new } \\
\text { disciplines } \\
\text { (contextual } \\
\text { knowledge, } \\
\text { business finances, } \\
\text { brands on the } \\
\text { market, sustainable } \\
\text { development) } \\
\end{array}$ & $23.13 \%$ & $\begin{array}{c}\text { knowledge of } \\
\text { organisation / basic } \\
\text { skills of managing } \\
\text { projects }\end{array}$ & $5.44 \%$ & $\begin{array}{l}\text { knowledge of } \\
\text { design (design / } \\
\text { / policy / } \\
\text { / research, } \\
\text { experience in } \\
\text { professional } \\
\text { design) }\end{array}$ & $4.76 \%$ \\
\hline & understanding & $\begin{array}{c}\text { knowledge of the } \\
\text { market, } \\
\text { stakeholders, } \\
\text { system, context, } \\
\text { good design criteria }\end{array}$ & $17.69 \%$ & $\begin{array}{l}\text { knowledge of the } \\
\text { relationship in the } \\
\text { process, projects, } \\
\text { business }\end{array}$ & $2.04 \%$ & $\begin{array}{c}\text { detailed } \\
\text { knowledge of } \\
\text { the design and } \\
\text { aesthetic sense }\end{array}$ & $4.08 \%$ \\
\hline & creative thinking & $\begin{array}{c}\text { versatility in } \\
\text { analytical and } \\
\text { intuitive thinking, } \\
\text { holistic thinking }\end{array}$ & $36.05 \%$ & $\begin{array}{l}\text { creating ideas, the } \\
\text { concept of the } \\
\text { replacement of } \\
\text { generations, } \\
\text { recognizing and } \\
\text { identifying with other } \\
\text { prospects / other } \\
\text { points of view }\end{array}$ & $2.72 \%$ & $\begin{array}{l}\text { replacement of } \\
\text { needs and } \\
\text { requirements } \\
\text { into creative } \\
\text { innovative ideas }\end{array}$ & $4.08 \%$ \\
\hline \multirow{2}{*}{ 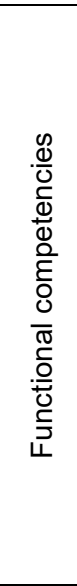 } & conceptual work & $\begin{array}{l}\text { clarification of the } \\
\text { vision, design goals } \\
\text { and adapting } \\
\text { business strategy, } \\
\text { managing project } \\
\text { assets / result }\end{array}$ & $36.05 \%$ & $\begin{array}{l}\text { managing project } \\
\text { team, project, } \\
\text { process, resources } \\
\text { (resources, } \\
\text { connecting, } \\
\text { coordinating) }\end{array}$ & $17.69 \%$ & $\begin{array}{l}\text { observation of } \\
\text { users/actual } \\
\text { context. } \\
\text { interpretation } \\
\text { and catching } \\
\text { talents needed } \\
\text { (use of different } \\
\text { research } \\
\text { methods and } \\
\text { tools) }\end{array}$ & $11.56 \%$ \\
\hline & implementation & $\begin{array}{l}\text { creating a consistent } \\
\text { overall experience } \\
\text { by all points of } \\
\text { design }\end{array}$ & $12.93 \%$ & $\begin{array}{c}\text { visualization of } \\
\text { information for } \\
\text { effective knowledge } \\
\text { exchange / } \\
\text { / cooperation }\end{array}$ & $6.80 \%$ & $\begin{array}{c}\text { skills in the } \\
\text { design and } \\
\text { implementation } \\
\text { of knowledge } \\
\text { (visualization, } \\
\text { prototype, } \\
\text { design tools) } \\
\end{array}$ & $21.09 \%$ \\
\hline \multirow{2}{*}{ 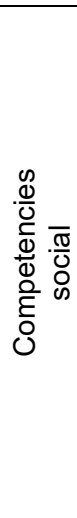 } & communication & $\begin{array}{c}\text { creating, } \\
\text { implementation, } \\
\text { sharing business / } \\
\text { / brand history, } \\
\text { (vision, goals) } \\
\text { between } \\
\text { stakeholders }\end{array}$ & $6.80 \%$ & $\begin{array}{l}\text { communicating with } \\
\text { all stakeholders / } \\
\text { / disciplines / users }\end{array}$ & $19.73 \%$ & $\begin{array}{c}\text { visual } \\
\text { communication; } \\
\text { visual } \\
\text { storytelling }\end{array}$ & $2.72 \%$ \\
\hline & relationships & $\begin{array}{l}\text { building / managing } \\
\text { strategic } \\
\text { relationships with } \\
\text { partners }\end{array}$ & $2.72 \%$ & $\begin{array}{c}\text { facilitating } \\
\text { (multidisciplinary) } \\
\text { cooperation, } \\
\text { relationship } \\
\text { management, } \\
\text { (conflicts, flexible } \\
\text { culture, motivation, } \\
\text { training) }\end{array}$ & $45.58 \%$ & $\begin{array}{c}\text { engaging } \\
\text { stakeholders / } \\
\text { / users in design } \\
\text { process }\end{array}$ & $8.16 \%$ \\
\hline \multirow{3}{*}{ 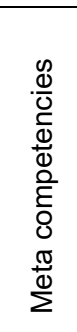 } & \multirow{3}{*}{ attitude / thought } & $\begin{array}{c}\text { uncertainty } \\
\text { tolerance / } \\
\text { / complexity } \\
\text { general perspective }\end{array}$ & $5.44 \%$ & $\begin{array}{c}\text { tolerance of } \\
\text { tensions and } \\
\text { conflicts, taking into } \\
\text { account diversity, } \\
\text { multifunctionality } \\
\end{array}$ & $2.72 \%$ & $\begin{array}{c}\text { multiple } \\
\text { initiatives of } \\
\text { improvement, } \\
\text { the pursuit of } \\
\text { high quality } \\
\end{array}$ & $6.12 \%$ \\
\hline & & \multicolumn{5}{|c|}{ creativity, innovation, challenge, search } & $6.80 \%$ \\
\hline & & \multicolumn{5}{|c|}{ empathy, flexibility, resilience, durability } & $26.53 \%$ \\
\hline
\end{tabular}

Source: Hyo-Jin Kang et al. (2015). 
This enables us to evaluate the real competencies, identify the competency gap, and identify the cause. While the literature emphasizes that the social capital of managers is embedded in $\mathrm{Cl}$ practices, it fails to specify or measure its causal role in their development (Robertie 2016).

Competency models are theoretical models, because they show the maximum achievable managerial competencies theoretically. They are also recognized as normative patterns, because they show the thresholds that determine both the minimum and maximum levels of a given competency (Whiddett and Hollyforde 2003).

Depending on the management level and the function that the manager performs, the competency models vary. Another important factor to pay attention to is the culture of the organization, whereby certain types of behaviour are acceptable and certain are not (Pocztowski and Miś 2000a).

Table 1 presents an overview of key competencies in the Polish literature of the subject. The presented model review points to a diverse approach to define the notion of competencies and at the same time reveals the author's approach based on the division of competencies into categories.

By analysing the models, it is clear that certain groups of competencies repeat, which was also pointed by Tomaszuk (2013). Among such competencies are: communication competencies, substantive competencies, implementation competencies, innovation competencies, team work competencies, foreign languages competencies and using IT competencies.

Competency (Table 2) model for managers including 3 levels: strategic, tactical, and including 26 competencies are presented by Hyo-Jin Kang, Kyung-won Chung, Ki-Young Nam.

\section{CRITERIA FOR EVALUATION OF MANAGERIAL COMPETENCIES}

Ratings are made through evaluation criteria. These are selected by the evaluator, which hypothetically or indeed is entitled to the subject matter. The value given is determined by the intensity of the appearance of certain characteristics. Sometimes it happens that the mere appearance of this qualification decides the value (Dziadon 1984).

The synthetic criterion for assessing the competencies of managers is the guarantee of integrating the evaluation of the company's functioning system with the system of individual assessment of manager's competencies. It is assumed that action is effective when it achieves its goals or facilitates achieving it (Stabryła and Trzcieniecki 1986). This does not have to be an effective operation, as costs can outweigh the benefits.

Effective targeting means "doing the right thing in the right way," at the same time, taking into account constraints imposed by the manager. They result from both its position as well as the situation of the company and the socio-economic environment (Stoner and Wanker 1992). 
A modelled approach in literature indicates the significant relationship between organizational effectiveness and managerial competencies. Among which are:

- a model for the effective management by J.C. Bavvon;

- the model of three-dimensional leadership of F. Hesslbein, M. Goldsmith, R. Bechhord;

- upper echelon by D.C. Hambrick, P. Mason;

- M.A. Carpenter's, M. Galetkanycz's, W. Sanders' model;

- cybernetic approach to effectiveness of management by J. Leon and J. Frąckiewicz;

- efficiency-competencies matrix, R. Walkowiak.

The concept of a balanced scorecard is an example of a practical, comprehensive selection of criteria for the assessment of the competencies of a manager. This method involves creating a set of assessment criteria, which are tailored to the specifics of the four areas for action of the organization (Kaplan and Norton 2001). The adopted criteria form the basis for assessing the efficiency and effectiveness of a manager. This is done by identifying the degree of implementation of assigned tasks. The long-term development of the company is also included. It allows a greater involvement of the company strategy with the evaluation system of manager competencies. The catalogue of specified competencies should be supplemented with ethical and psychological criteria.

Clarification of methods to assess competencies is carried out using three criteria. The first of the criteria takes into account the multidisciplinary nature of the competencies dividing the methods into: behavioural, psychological, and the methods of measuring intellectual capital. The second criterion is based on the subject of evaluation. While the third criterion divides the methods of assessment of competencies into methods for measuring real and model competencies.

Based on management sciences, organisational methods were formed. They are divided into the universal and specific. They can also be comprehensive or fragmentary (Stabryła 2009).

Psychological methods rely on diagnosing the behaviour of managers. They include psychological tests. They allow exploring the intelligence, personality and attitude to perform various actions (Baraniak 2009). They are found mainly in the form of questions or sets of tasks.

Behavioural methods apply to subjective aspects. They are related to the behaviour, which accentuates the role of external determinants. The Table 3 below shows the classification of the recognised methods of assessing competencies of the managers.

The goal of the presented methods is to determine the patterns of competencies by comparing the standard and actual competency gap and the determination of the levels of competencies. These results can be used in human resource management, for example, recruitment, development and wage setting.

Classification, according to the phases of the process of evaluating competencies, is divided into two categories: methods for measuring the actual competency that the evaluated manager has, and methods identifying the core competency (Table 4).

Method of assessment of competence should be selected in such a way that it is possible to fully describe the manager tested (Pocztowski and Miś 2000b). This decision should be also made by taking in consideration the following aspects:

- the objective of the assessment,

- a kind of competencies evaluated, 
- economic and financial condition,

- the size of the company,

- the competencies of the entities in charge of personnel policies.

Table 3. Selected methods for the evaluation of managerial competencies

\begin{tabular}{|c|c|c|c|}
\hline \multicolumn{4}{|c|}{ Organisational methods } \\
\hline \multicolumn{4}{|c|}{$\begin{array}{l}\text { - analysis of mission and strategy of the company } \\
\text { - analysis of work } \\
\text { - knowledge assessment } \\
\text { - job description cards } \\
\text { - methods of valuating competencies } \\
\text { - benchmarking of managerial competencies } \\
\text { - audit of managerial competencies } \\
\text { - SWOT analysis } \\
\text { - performance management } \\
\text { - management by objectives } \\
\text { - managerial and administrative contacts }\end{array}$} \\
\hline \multicolumn{4}{|c|}{ Psychological methods } \\
\hline \multicolumn{4}{|l|}{$\begin{array}{l}\text { - personality tests } \\
\text { - e-interplace } \\
\text { - performance tests } \\
\text { - intelligence tests } \\
\text { - aptitude tests } \\
\text { - interest tests } \\
\text { - career maturity tests }\end{array}$} \\
\hline \multicolumn{4}{|c|}{ Behavioural methods } \\
\hline \multicolumn{4}{|c|}{$\begin{array}{l}\text { - observation } \\
\text { - analysis of resumes } \\
\text { - analysis of the letters of intent } \\
\text { - expert panels } \\
\text { - assessment centre } \\
\text { - development centre } \\
\text { - behavioural-diagnostic interviews } \\
\text { - skills assessment } \\
\text { - } 360 \text { degrees feedback } \\
\text { - personal portfolio } \\
\text { - management styles assessment } \\
\text { - critical incident technique } \\
\text { - competency model } \\
\text { - competency profile } \\
\text { - letters of competency } \\
\text { - analysis of biography } \\
\text { - genogram }\end{array}$} \\
\hline \multicolumn{4}{|c|}{ The method of measuring intellectual capital } \\
\hline direct methods & $\begin{array}{c}\text { methods based on the } \\
\text { market value }\end{array}$ & $\begin{array}{l}\text { methods based on the } \\
\text { return on assets }\end{array}$ & methods of scorecards \\
\hline $\begin{array}{l}\text { - Technology Broker } \\
\text { (1996) } \\
\text { - Citation-Weighted } \\
\text { Patents (1996) } \\
\text { - Inclusive Valuation } \\
\text { Methodology - IVM } \\
\text { (1998) } \\
\text { - Accounting For The } \\
\text { Future - AFTF (1998) } \\
\text { - The Value ExplorerTM } \\
\text { (2000) } \\
\text { - Intelectual Asset } \\
\text { Valuation }\end{array}$ & $\begin{aligned} \text { - } & \text { the Tobin Q. } \\
& (1997,1999) \\
- & \text { Investor Assigned } \\
& \text { Market Value-IAMVTM } \\
& (1998) \\
- & \text { Market-to-Book Value } \\
& (1997,1998)\end{aligned}$ & $\begin{array}{l}\text { - Human Resources } \\
\text { Costing and Accounting } \\
\text { - HRCA (1996) } \\
\text { - Economic Value } \\
\text { Added-EVATM (1997) } \\
\text { - Calculated Intangible } \\
\text { Value (1997, 1998) } \\
\text { - Knowledge Capital } \\
\text { Earnings (1999) }\end{array}$ & $\begin{array}{l}\text { - The Balanced } \\
\text { Scorecard (1992) } \\
\text { - Human Capital } \\
\text { Intelligence (1994) } \\
\text { - Scandia NavigatorTM } \\
\text { (1997) } \\
\text { - IC-IndexTM smart } \\
\text { scale (1997) } \\
\text { - Intangible Assets } \\
\text { Monitor (1997) } \\
\text { - The Value Added } \\
\text { Intellectual Coefficient- } \\
\text { VAICTM (1997) } \\
\text { - Value Chain } \\
\text { ScorecardTM (2001) }\end{array}$ \\
\hline
\end{tabular}

Source: Tyrańska (2011). 
Table 4. Classification of methods of assessment of competencies according to the phases of the evaluation process, the competency of managers

\begin{tabular}{|c|c|c|c|}
\hline \multicolumn{4}{|c|}{ Identifying benchmark competencies } \\
\hline \multicolumn{2}{|c|}{$\begin{array}{l}\text { Techniques based on previous experiences, identifying } \\
\text { the competencies evaluated in an organization: } \\
\text { - the study of archives } \\
\text { - job description cards of managerial positions } \\
\text { - interviews with managers } \\
\text { - observation } \\
\text { - critical incident technique } \\
\text { - panels of experts }\end{array}$} & \multicolumn{2}{|c|}{$\begin{array}{l}\text { Techniques based on the projection of the future require a clear } \\
\text { vision of the future. After the analysis of the external and } \\
\text { internal conditions, managerial competencies are forecast that } \\
\text { the company will need for the achievement of its objectives. } \\
\text { These techniques include: } \\
\text { - analysis of mission and strategy of the company } \\
\text { - the methods of measuring intellectual capital } \\
\text { - panels of experts } \\
\text { - competency model } \\
\text { - competency profile } \\
\text { - letters of competency }\end{array}$} \\
\hline \multicolumn{4}{|c|}{ Measurement of core competencies } \\
\hline $\begin{array}{l}\text { organisational methods: } \\
\text { - knowledge assessment } \\
\text { - methods of valuating com- } \\
\text { petencies } \\
\text { - audit of managerial com- } \\
\text { petencies } \\
\text { - benchmarking of managerial } \\
\text { competencies } \\
\text { - SWOT analysis } \\
\text { - management by objectives } \\
\text { - performance management } \\
\text { - managerial and administra- } \\
\text { tive contacts }\end{array}$ & $\begin{array}{l}\text { psychological } \\
\text { methods }\end{array}$ & $\begin{array}{l}\text { behavioural methods: } \\
\text { - observation } \\
\text { - analysis of resumes } \\
\text { - analysis of the letters of intent } \\
\text { - assessment centres } \\
\text { - development centre } \\
\text { - behavioural-diagnostic interviews } \\
\text { - balance assessment } \\
\text { - } 360 \text { degrees feedback } \\
\text { - personal portfolio } \\
\text { - management styles assessment } \\
\text { - critical incident technique } \\
\text { - competency profile } \\
\text { - letters of competency } \\
\text { - analysis of biography } \\
\text { - genogram }\end{array}$ & $\begin{array}{l}\text { methods for the measu- } \\
\text { rement of human capital }\end{array}$ \\
\hline
\end{tabular}

Source: Tyrańska (2011).

\section{THE COMPETENCIES OF THE MANAGERS OF SMALL AND MEDIUM-SIZED ENTERPRISES - OWN RESEARCH}

The aim of the study was to get the opinion of managers on the skills needed and characteristics that should display.

Table 5. Characteristics of managers involved in the study N-200

\begin{tabular}{|c|c|c|c|}
\hline Specification & Characteristics & Number & Percentage \\
\hline \multirow{4}{*}{ Age } & to 25 years & 30 & 15.0 \\
\hline & $25-35$ years & 65 & 32.5 \\
\hline & $35-45$ years & 83 & 41.5 \\
\hline & over 45 years & 22 & 11.0 \\
\hline \multirow{2}{*}{ Sex } & women & 89 & 44.5 \\
\hline & men & 111 & 55.5 \\
\hline \multirow{3}{*}{ Education } & higher & 125 & 62.5 \\
\hline & secondary education & 65 & 32.5 \\
\hline & vocational & 10 & 5.0 \\
\hline \multirow{5}{*}{ Seniority } & to 5 years & 24 & 12.0 \\
\hline & $5-10$ years & 35 & 17.5 \\
\hline & $10-15$ years & 57 & 28.5 \\
\hline & $15-20$ years & 63 & 31.5 \\
\hline & 20 years & 21 & 10.5 \\
\hline \multirow{5}{*}{$\begin{array}{l}\text { Number of } \\
\text { subordinates }\end{array}$} & up to 9 pers. & 56 & 28.0 \\
\hline & 10-20 pers. & 64 & 32.0 \\
\hline & $21-30$ pers. & 28 & 14.0 \\
\hline & $31-40$ pers. & 31 & 15.5 \\
\hline & $41-50$ pers. & 21 & 10.5 \\
\hline \multirow{3}{*}{$\begin{array}{l}\text { Management } \\
\text { level }\end{array}$} & first line manager (foreman, shift manager) & 57 & 28.5 \\
\hline & middle management & 85 & 42.5 \\
\hline & the top-level management (president, CEO, owner) & 58 & 29.0 \\
\hline
\end{tabular}


The studies were conducted in May 2016. The subject of the study were 200 managers leading small and medium-sized enterprises in Masovian and Podlaskie Voivodeships representing the three levels of management. The study was carried out by means of structured interview. The questionnaire consisted of multiple choice questions. The questionnaire was the survey research tool. Detailed characteristics of the respondents are shown in Table 5.

\section{RESEARCH RESULTS}

Respondents identified characteristics, which a modern manager should display (Fig. 1). Responsibility was the most important characteristic indicated by the respondents $(90 \%$ of respondents). According to $80 \%$ of the respondents, creativity is a feature that should characterize the modern manager. The least pointed characteristics were the dynamism and ability to cooperate. Particularly puzzling is the low percentage of indications on the ability to cooperate. This skill is important, as evidenced by the results presented in table 6 where respondents evaluated the need for manager's skills depending on the level of management.

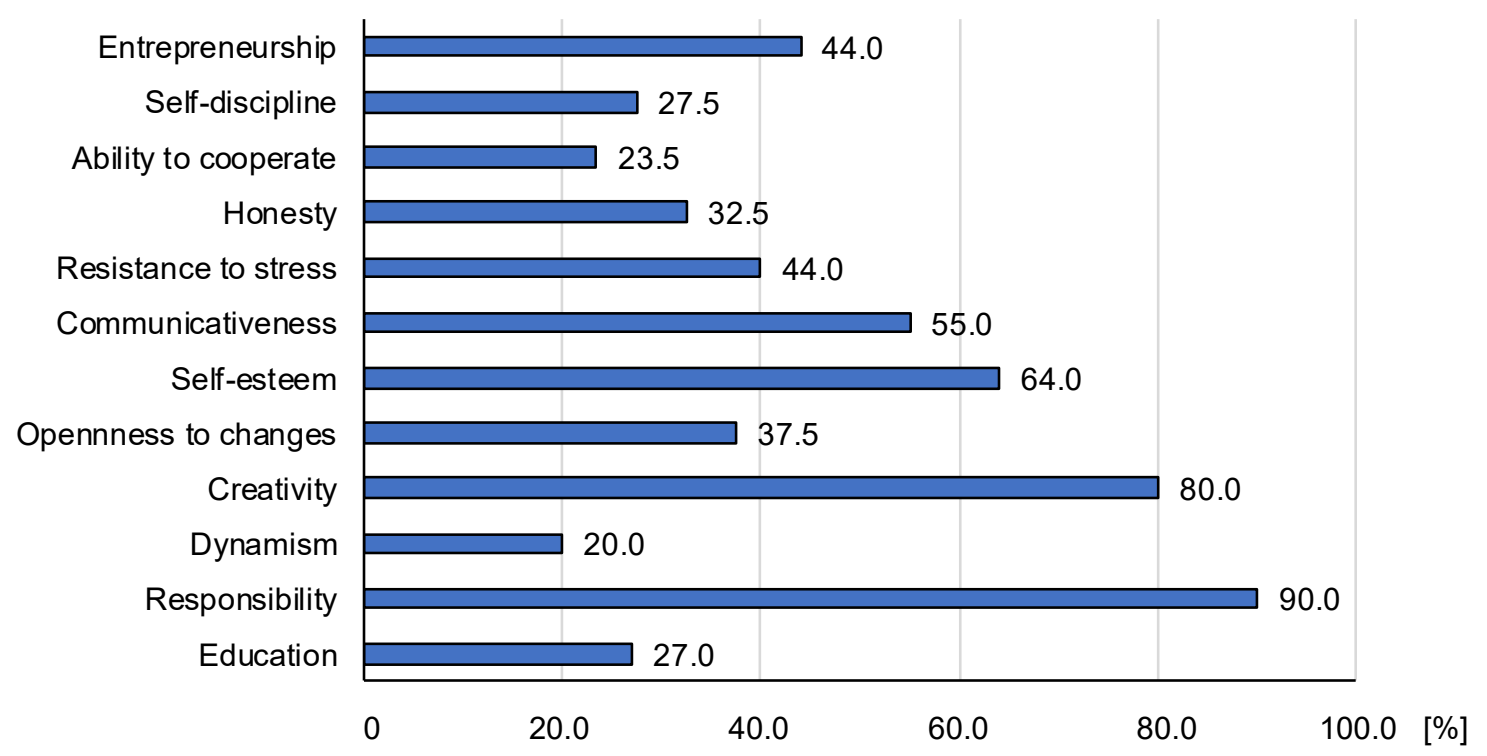

Fig. 1. Characteristics of the modern manager, in the opinion of the respondents

Managers also indicated which skills they think a modern manager should display. In contrast to the results presented in Fig. 1, the most often indicated was the ability to build relationships with subordinates $(78.5 \%$ responses). Often indicated skills were also: communication, decision making, fast learning. According to the managers, skills such as conflict resolution and technical skills are the least needed (Fig. 2).

Respondents also were asked to identify which skills a manager should possess, depending on the management level (Table 6). The importance of skills in the opinion of the respondents is in line with the traditional perception of them by the managers. First-line managers should primarily possess technical skills, however, leadership skills, negotiation skills, or time 
management, according to the respondents, should be the domain of senior managers. The perception of building relationships with subordinates should be considered as interesting. This ability was identified by managers as important regardless the management level.

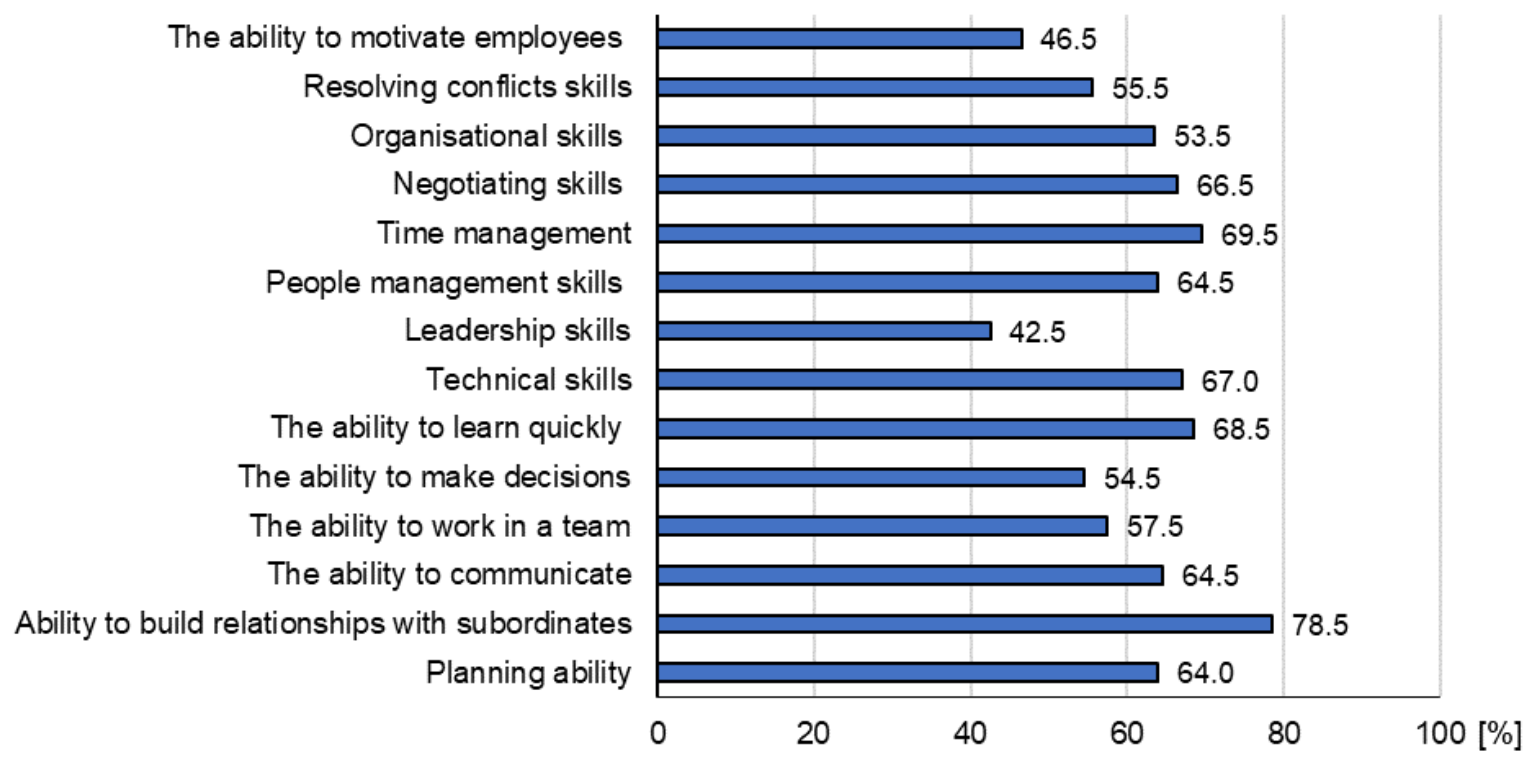

Fig. 2. The necessary skills, which a modern manager should possess in view of respondents

Table 6. The skills a manager should possess depending on the management level in the opinion of respondents $\mathrm{N}-200$

\begin{tabular}{|l|c|c|c|}
\hline Specification & $\begin{array}{c}\text { The top-level } \\
\text { management } \\
\text { (president, CEO) [\%] }\end{array}$ & Middle management & $\begin{array}{c}\text { First line manager } \\
\text { (foreman, shift } \\
\text { manager) [\%] }\end{array}$ \\
\hline Technical skills & 25.9 & 31.8 & 89.5 \\
\hline Leadership skills & 93.1 & 35.3 & 47.4 \\
\hline People management skills & 60.3 & 56.5 & 77.2 \\
\hline Time management & 87.9 & 60.0 & 54.4 \\
\hline Negotiating skills & 91.4 & 62.4 & 57.9 \\
\hline Organisational skills & 72.4 & 49.4 & 37.2 \\
\hline Resolving conflicts skills & 65.5 & 30.6 & 63.2 \\
\hline The ability to learn quickly & 77.6 & 62.4 & 77.2 \\
\hline The ability to make decisions & 81.0 & 54.1 & 61.4 \\
\hline The ability to motivate employees & 65.5 & 42.4 & 73.7 \\
\hline The ability to work in a team & 60.3 & 44.7 & 66.7 \\
\hline The ability to communicate & 74.1 & 56.5 & 82.5 \\
\hline $\begin{array}{l}\text { The ability to build relationships with } \\
\text { subordinates }\end{array}$ & 77.6 & 76.5 & 63.2 \\
\hline Planning ability & 81.0 & 52.9 & \\
\hline
\end{tabular}

\section{CONCLUSIONS}

Contemporary managers must constantly improve their skills and adapt to market developments and trends that are taking place in the management of human resources. These changes are determined by new generations entering the labour market and them having different expectations of work and hence also of the superior. To be able to fulfil their tasks properly, managers must be relevant. An appropriate set of characteristics and skills is 
a prerequisite for the effectiveness and efficiency of work. However, as the review of the results of research of different authors and own research, there is no single universal set that would guarantee success, which Stolarska highlights stating that there is no single feature of the leadership, nor the set that would provide success in any situation, however, she also indicates that the ability to influence people deliberately and purposefully, is one of the key skills of effective manager-leader (Stolaska 2012).

The research indicates that relationships with employees are important for managers. This is confirmed by Kalińska's research (Kalinska 2013), which as one of the important tasks of the manager indicates "giving the model of positive relationship within the team."

Analysis of the results of research and the literature points to the need for further research into the importance of relationship building skills by managers with subordinates, because this skill emerges as one of the key for contemporary managers.

\section{REFERENCES}

Baraniak B. 2009. Methods for research of work. Warszawa, Wydaw. Akademickie i Profesjonalne.

Burgoyne J., Hirsh W., Williams S. 2004. The development of management and leadership capability and its contribution to performance: The evidence, the prospects and the research need. Research Report RR560, Lancaster University.

Dziadoń J. 1984. Shaping normative patterns for assessing the organizational structure of an enterprise. Sci. J. Acad. Econ. Kraków, 195, 94.

Hyo-Jin K., Kyung-won Ch., Ki-Young N. 2015. A competence model for design managers: A case study of middle managers in Korea. Intern. J. Design. V. 9(2)2, http://www.ijdesign.org/ /ojs/index.php/IJDesign/article/view/1957/700, access: 14.03.2017.

Kaczmarek B. 2016. Contemporary challenges for business management. Toruń, Tow. Nauk. Org. Kier.

Kalinska M. 2013. Mid-level managers roles in building the positive potential of the organization. Part 2. Manag. Fin., http://jmf.wzr.pl/pim/2013_4_2_13. PDF file, access: 4.01.2017.

Kaplan R.S., Norton D.P. 2001. Balanced scorecard. Translating strategy into action. Warszawa PWN.

Khorasani A., Vajargah K.F., Zahedi H. 2014. Designing a business management competency model for Iranian Industrial and Manufacturing Organizations. Int. J. Soc. Sci. Manag. 1(1), 1-13.

Levy-Leboyer C. 1997. Managing competencies. The balance of professional experience. Warszawa, Poltext.

Molinsky A., Davenport T.H., lyer B., Davidson C.N. 2012. Three skills every 21st-century manager needs, https://hbr.org/2012/01/three-skills-every-21st-century-manager-needs, access: 4.01.2017.

Papula J. 1995. Minimum of a manager: Profession that pays out, in: Importance of managerial skills and knowledge in management for small entrepreneurs. Eds. Z. Papulová, M. Mokroš. Prague, E-Leader, https://www.g-casa.com/PDF/Papulova-Mokros.pdf, access: 5.02.2017.

Papulová Z., Mokroš M. 2007. Importance of managerial skills and Knowledge in management for small entrepreneurs, Prague, E-Leader, https://www.g-casa.com/PDF/Papulova-Mokros.pdf, access: 14.03.2017.

Pocztowski A., Miś A. 2000. Managerial competency modeling in terms of human capital in organization, in: Shaping the human capital of the company. Ed. B. Kożuch. Białystok, Wydaw. Uniwersytetu w Białymstoku.

Pocztowski A., Miś A. 2000a. Analysis of human resources in organization. Kraków, AE.

Robertie C. 2016. Top managers networking influence on competitive intelligence practices: The case of Hi-Tech SMBs. Eur. Res. Stud. J. 19(4), 158-169.

Skills that will make you indispensable, http://www.amanet.org/training/promotions/six-skills-formanagers.aspx: access 4.01.2017. 
Stabryła A. 2009. Improvement of the organizational structures of enterprises in a knowledge-based economy. Warszawa, C.H. Beck.

Stabryła A., Trzcieniecki J. 1986. Organisation and management. Outline of issues. Warszawa, PWN.

Stolaska D. 2012. The ability to influence people as a key competence of the modern manager and leader - case study. Econ. Manag. 3, 194.

Stoner J.A., Wanker F. 1992. Directing, Warszawa, PWE.

Tomaszuk A. 2013. Picture of the manager in the light of the manager management theory and own research on the example of the construction sector managers in Podlaskie Voivodeship, Econ. Manag. 4, http://www.zneiz.pb.edu.pl/date/magazine/article/308/1.5_tomaszuk. pdf.

Tyrańska M. 2011. Manager competencies assessment system, in: The review of problems of managing businesses developing systems. Ed. A. Stabryła. Kraków, Mfiles.

Whiddett S., Hollyforde S. 2003. Competency models in human resources management, Kraków Oficyna Ekonomiczna.

Summary. The theoretical part of the article discusses the importance of competencies, indicating which of them are the most important in the light of the research of various authors. Selected models of managerial competencies were discussed. The article also presents the results of own research. The research was carried out among 200 managers from small and medium enterprises from Masovian and Podlaskie voivodeships representing 3 levels of management. The aim of the study was to get acquainted with the views of managers on the importance of competencies and skills they needed. Own studies and literature indicate that one of the key skills of a modern manager is the ability to build relationships with subordinates. 
